\title{
Distribution of galanin immunoreactivity in the respiratory tract of pig, guinea pig, rat, and dog
}

\author{
A CHEUNG, JMPOLAK, FE BAUER, A CADIEUX, ND CHRISTOFIDES, \\ DR SPRINGALL, SR BLOOM
}

From the Departments of Histochemistry and Medicine, Royal Postgraduate Medical School, London

ABSTRACT Galanin, a newly discovered peptide isolated from porcine intestine, is known to cause contraction in rat smooth muscle preparations and to induce hyperglycaemia in dogs. By the use of radioimmunoassay and immunohistochemical techniques the concentration and distribution of galanin immunoreactivity were determined in several areas of the respiratory tract of five dogs, five guinea pigs, five rats, and two pigs. Antibodies were raised in rabbits to whole unconjugated natural porcine galanin. The highest galanin concentrations were found in the bronchus and the trachea of the dog, guinea pig, rat $(2 \mathrm{pmol} / \mathrm{g}$ in each case), and pig $(<1 \mathrm{pmol} / \mathrm{g})$. The lowest galanin concentrations were found in the lung parenchyma. Gel chromatographic analysis in the pig showed one molecular form of galanin coeluting with the porcine galanin standard. By means of the indirect immunofluorescence technique on sections of tissues fixed in benzoquinone solution, galanin was found to be confined to nerve fibres in different regions of the respiratory tract. In the nasal mucosa of the pig nerve fibres containing galanin were distributed around seromucous glands and blood vessels and beneath the epithelium. In the trachea, bronchus, and major intrapulmonary airways of the pig, dog, and guinea pig galanin immunoreactive fibres were detected predominantly in smooth muscle, as well as around seromucous glands and in the adventitia of blood vessels. Rarely, galanin immunoreactive nerve fibres were found in the lung parenchyma. A few galanin immunoreactive ganglion cells also containing vasoactive intestinal polypeptide were found in the adventitia of the tracheobronchial wall of the pig and dog. The distribution of galanin suggests that it may have some influence on airway, vascular, and secretory functions in the mammalian respiratory tract.

During a systematic search for peptides with a $C$ terminal amidated structure, Tatemoto et al $^{1}$ discovered and isolated a 29 amino acid peptide from the porcine gastrointestinal tract. This newly discovered peptide, designated galanin because of its $N$ terminal glycine and $C$-terminal alanine amide residues, was shown to contract smooth muscle preparations from the rat and to cause a mild and sustained hyperglycaemic response in dogs. ${ }^{12}$ Recently, galanin like immunoreactivity has been reported in the central nervous system, gastrointestinal tract, and urogenital tract of mammals, including man. ${ }^{3-5}$

The mammalian respiratory tract is known to be under the control of the autonomic nervous system. ${ }^{6}$ In addition to the classical cholinergic and adrenergic miechanisms, the presence of a third component of the

Address for reprint requests: Dr JM Polak, Department of Histochemistry, Royal Postgraduate Medical School, London W120HS.

Accepted 25 June 1985 autonomic nervous system regulating airway smooth muscle tone and other physiological processes in the lung has been postulated. ${ }^{7-10}$ There is increasing evidence to suggest that the neurotransmitters in this non-cholinergic, non-adrenergic nervous system are peptides. ${ }^{10}$ In the last few years more than 10 bioactive peptides have been demonstrated in the mammalian respiratory tract ${ }^{11}$. Bombesin, calcitonin, and leu-enkephalin have been localised by immunocytochemical methods to bronchial endocrine cells, ${ }^{12-16}$ while substance $P,{ }^{1718}$ vasoactive intestinal polypeptide, ${ }^{1920}$ peptide histidine isoleucine, ${ }^{21}$ and neuropeptide tyrosine ${ }^{22}$ are found in the lung innervation. Recently calcitonin gene related peptide ${ }^{23}$ has been found in both endocrine cells and nerves of the mammalian respiratory tract. Other peptides, including cholecystokinin and somatostatin, have been detected by radioimmunoassay. ${ }^{24}$

The aim of the present study is to investigate the possible occurrence and distribution of the newly iso- 
Table 1 Characteristics of galanin antisera

\begin{tabular}{|c|c|c|}
\hline & Immunocytochemistry & Radioimmunoassay \\
\hline $\begin{array}{l}\text { Donor } \\
\text { Hapten } \\
\text { Antibody dilution } \\
\text { Assay standard } \\
\text { Assay sensitivity } \\
\text { (fmol/assay tube) } \\
\text { No cross reaction } \\
\text { with peptides } \\
\text { Staining inhibition }\end{array}$ & $\begin{array}{l}\text { SP, NPY, CGRP, } \\
\text { VIP, PHI } \\
\text { Porcine intestinal } \\
\text { galanin }\end{array}$ & $\begin{array}{l}\text { Rabbits } 8 \text { and } 9 \\
\text { Porcine intestinal } \\
\text { galanin } \\
1 / 480000 \text { for rabbit } 8 \\
1 / 48000 \text { for rabbit } 9 \\
\text { Porcine intestinal } \\
\text { galanin } \\
2 \\
\text { SP, GnRH, VIP, } \\
\text { ACTH, PHYS }\end{array}$ \\
\hline
\end{tabular}

SP-substance P; NPY - neuropeptide tyrosine; CGRP-calcitonin gene related peptide; VIP - vasoactive intestinal polypeptide; PHI-peptide histidine isoleucine; GnRH-gonadotrophin releasing hormone; ACTH - adrenocorticotrophic hormone; PHYS - physalaemin.

lated peptide galanin in the mammalian respiratory tract by immunocytochemical methods and radioimmunoassay.

\section{TISSUES}

The respiratory tract was dissected from two piglets and five dogs. In each case samples were taken from the trachea (upper, middle, and lower), major bronchi, the inner lung containing the minor bronchi, the middle lung containing medium sized bronchi, and the outer (peripheral) lung including alveoli. Nasal mucosa was also obtained from the two piglets. Similar areas (trachea, major bronchi, and lung) were dissected out from five guinea pigs and five rats. The tissue samples were divided and processed for immunocytochemical study and radioimmunoassay.

\section{IMMUNOCYTOCHEMICAL STUDY}

Pieces of tissue from each area, measuring no more than $1 \times 1 \times 0.5 \mathrm{~cm}$, were fixed by immersion in $0.4 \%$ para-benzoquinone in phosphate buffered saline (PBS) $(0.01 \mathrm{~mol} / 1, \mathrm{pH} 7.1-7.4)$ for two hours. ${ }^{25}$ The tissue was then washed overnight at $4^{\circ} \mathrm{C}$ in PBS containing $15 \%$ sucrose and $0.01 \%$ sodium azide, snap frozen and made into cryostat blocks. Several serial sections were cut at a thickness of $10 \mu \mathrm{m}$ in a cryostat at $-20^{\circ} \mathrm{C}$, collected on poly-L-lysine coated slides, ${ }^{26}$ and allowed to dry at room temperature for one hour. The sections were soaked for half an hour in PBS containing $0.2 \%$ Triton $\mathrm{X}-100$ and immunostained by the indirect immunofluorescence method. ${ }^{27}$ The sections were incubated overnight at $4^{\circ} \mathrm{C}$ with either antibody to galanin at a dilution of 1:1000 or antibody to vasoactive intestinal polypeptide (1:2000). The second layer of fluorescein conjugated antirabbit gammaglobulin was applied at a dilution of $1: 100$ for one hour. Sections were mounted in PBS-glycerol (1:1) and examined with a Leitz fluorescence microscope. Control for method specificity included replacement of the first layer antibody with non-immune rabbit serum.

\section{RADIOIMMUNOASSA Y \\ Tissue extraction}

Fresh preweighed tissue samples from the different animals were put into polypropylene tubes containing $0.5 \mathrm{~mol} / \mathrm{l}$ acetic acid (about $10 \mathrm{ml} / \mathrm{g}$ tissue) at $100^{\circ} \mathrm{C}$ and heated for 20 minutes in a boiling water bath. The samples were then cooled and stored at $-20^{\circ} \mathrm{C}$ until assay. Aliquots of $20 \mu \mathrm{l}$ of tissue extracts were assayed in duplicate in a total volume of $800 \mu \mathrm{l}$.

\section{Radioimmunoassay procedure}

The radioimmunoassay for galanin is described elsewhere. ${ }^{28}$ Briefly, iodination of galanin was performed by the chloramine $T$ method and the label purified by reverse phase high performance chromatography on a micro Bondapak C-18 column, being eluted with $30 \%$ acetonitrile in an aqueous solution of $0.1 \%$ trifluoracetic acid. The specific activity of the label was $60 \mathrm{Bequerel} / \mathrm{fmol}(1.62 \mathrm{nCi} / \mathrm{fmol})$. Cross reactivity studies were performed with the galanin antibodies and label, with serial additions of several other peptides (table 1).

\section{ANTISERA}

The antisera used for the immunocytochemical studies and radioimmunoassay were produced by immunising rabbits with unconjugated natural porcine galanin. The characteristics of the antisera are summarised in table 1.

Preabsorption of the galanin antiserum with as little as $0.1 \mathrm{nmol}$ of synthetic porcine galanin per $\mathrm{ml}$ of diluted antibody completely abolished immunostaining, whereas addition of synthetic substance $P$, neuropeptide tyrosine, calcitonin gene related peptide, vasoactive intestinal polypeptide, or peptide histidine isoleucine at $10 \mathrm{nmol}$ per $\mathrm{ml}$ of diluted antiserum did not affect immunostaining.

Furthermore, radioimmunoassay showed that there was no cross-reactivity of the antibodies with gonadotrophin releasing hormone, vasoactive intestinal polypeptide, adrenocorticotrophic hormone, physalaemin, or substance $P$ in peptide concentrations of up to $10 \mathrm{pmol} /$ tube.

\section{CHROMATOGRA PHY}

Three extracts of pig trachea and porcine galanin standard were loaded on a $100 \times 1.5 \mathrm{~cm}$ column of Sephadex G50 superfine (Pharmacia) and eluted at $4^{\circ} \mathrm{C}$ with $60 \mathrm{mmol} / 1$ phosphate buffer, $\mathrm{pH} 7.4$ containing $0.2 \mathrm{~mol} / 1$ sodium chloride, $10 \mathrm{mmol} / 1$ EDTA, and $1 \%$ bovine serum albumin at a flow rate of 


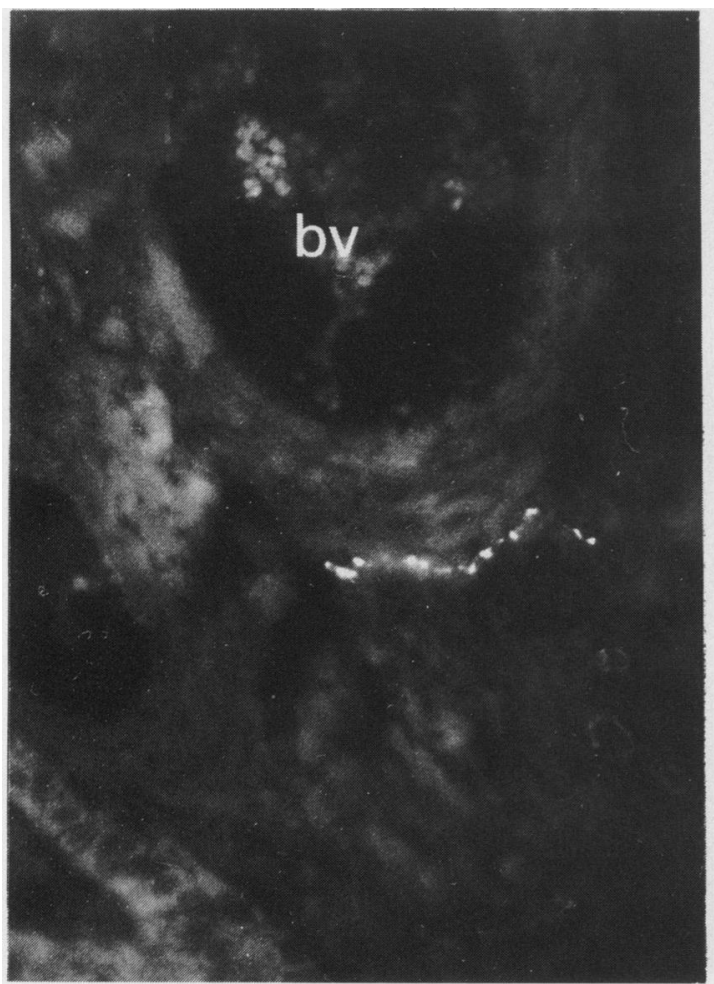

Fig 1 Nerve fibre containing galanin in the adventitia of a vein (bv) in porcine nasal mucosa (indirect immunofluorescence, $\times 350$.)

$6.0 \mathrm{ml} /$ hour. The pig samples were microfiltrated with Sep Pak (Waters). Elution of $10 \mathrm{ml}$ of tissue extract was carried out with $1.5 \mathrm{ml}$ of $50 \%$ acetonitrile containing $0.05 \%$ trifluoracetic acid and then evaporated, the volume being reduced to $0.5 \mathrm{ml}$ before being put in the column. Fractions of $2.0 \mathrm{ml}$ were collected for subsequent radioimmunoassay. The internal column markers used were dextran blue (molecular weight 2 $\times 10^{6}$, indicating void volume [Vo]), horse heart cytochrome C (molecular weight 12284), and a trace amount of sodium iodide (indicating total volume [Vt]). The elution positive (Ve) was expressed as the elution coefficient (Kav), where $\mathrm{Kav}=\mathrm{Ve}-\mathrm{Vo} / \mathrm{Vt}$ - Vo, according to the method of Laurent and Killander. ${ }^{29}$ The samples were measured in duplicate by a sample addition of $700 \mu \mathrm{l}$.

\section{STATISTICAL ANALYSIS}

Statistical analysis was performed by means of Friedman's two way analysis of variance by ranks. ${ }^{30}$

\section{Results}

\section{IMMUNOCYTOCHEMICAL STUDY}

Galanin

Galanin like immunoreactivity was localised to nerve

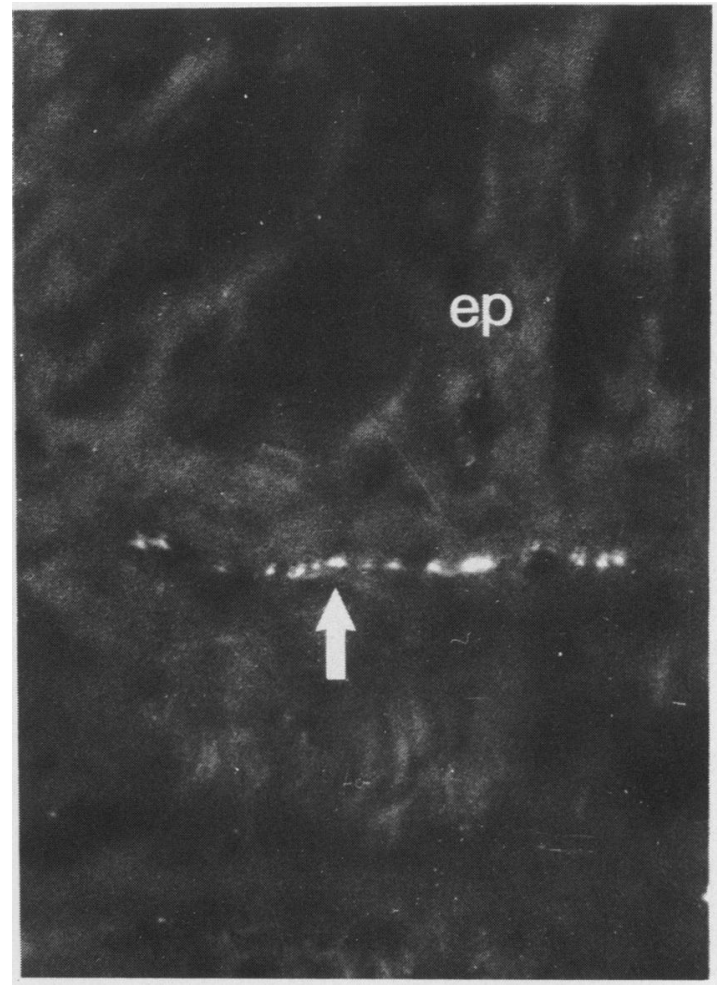

Fig 2 Fine galanin immunoreactive nerve fibre (arrow) running beneath the epithelium (ep) in porcine nasal mucosa (indirect immunofluorescence, $\times 600$.)

fibres in the respiratory tract of pigs, dogs, and guinea pigs. No galanin immunoreactive fibres were found in the rat respiratory tract.

Pig In the nasal mucosa fine galanin immunoreactive nerve fibres were frequently found in close association with seromucous glands and in the advantitia of blood vessels (fig 1 ). Occasionally, fine varicose fibres could be seen running beneath the epithelium (fig 2). On the whole, galanin immunoreactive nerve fibres were more numerous in the upper part of the respiratory tract and diminished in density towards the bronchi. In trachea and bronchi the most prominent site of galanin immunoreactivity was in the airway smooth muscle (fig 3 ). In the submucosa single varicose fibres were seen around seromucous glands (fig 4) as well as at the medial adventitial junction of blood vessels. Some nerve fibres containing galanin also occurred in nerve bundles in the perichondrium and in the adventitia of the trachea. Galanin immunoreactivity was rarely detected in the lung tissue except occasionally around minor intrapulmonary bronchi. Some small immunoreactive ganglion cells were observed in the adventitia of the trachea and bronchi (fig 5), particularly in the dorsal tracheobronchial wall, between and outside the cartilage 


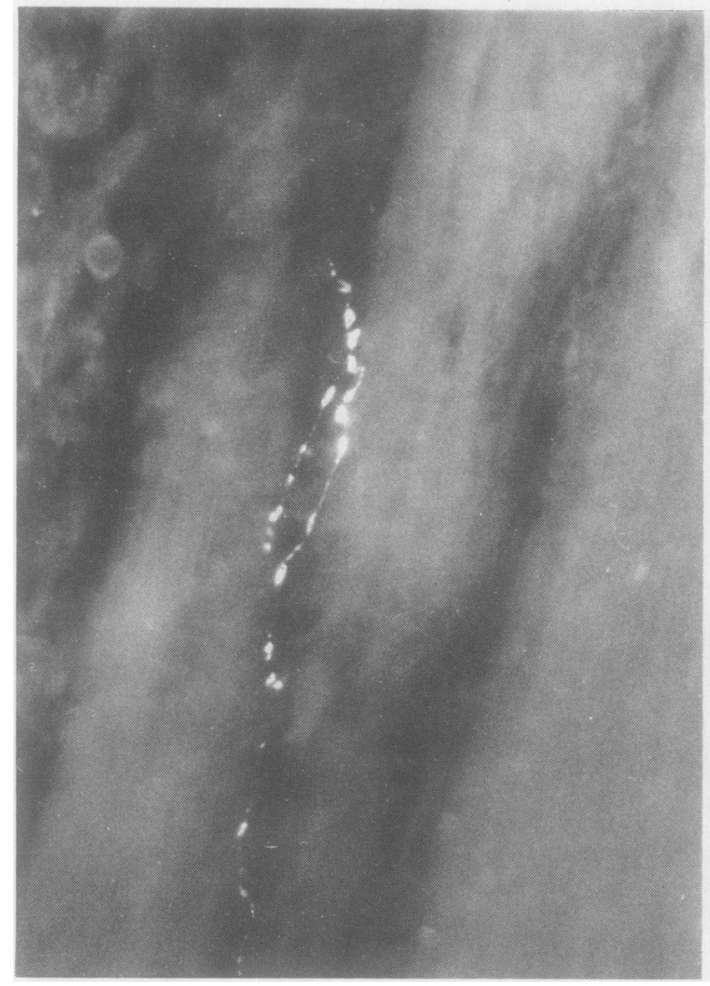

Fig 3 Galanin-immunoreactive nerve fibres in the smooth muscle of the porcine trachea (indirect immunofluorescence, $\times 350$.)

plates.

Dog In trachea and bronchus, galanin immunoreactive nerve fibres were also seen among smooth muscle and seromucous glands, around blood vessels (mainly arteries), and in ganglion cells. In contrast to the findings in the pig, galanin positive fibres in the dog were more abundant in the major bronchi (including the intrapulmonary ones) than in the trachea. The immunoreactive fibres formed a complex network among the smooth muscles of the airways (fig 6). Occasionally some fine varicose immunoreactive fibres were also observed around small blood vessels in the lung.

Guinea pig The respiratory tract of the guinea pig contained only a few galanin immunoreactive nerves, which were concentrated in the upper part of the trachea. As in the pig and dog, these fibres were mainly present among smooth muscles and around small blood vessels.

\section{Vasoactive intestinal polypeptide}

Vasoactive intestinal polypeptide immunoreactive nerve fibres have a strikingly similar distribution to galanin containing nerve fibres, being located chiefly

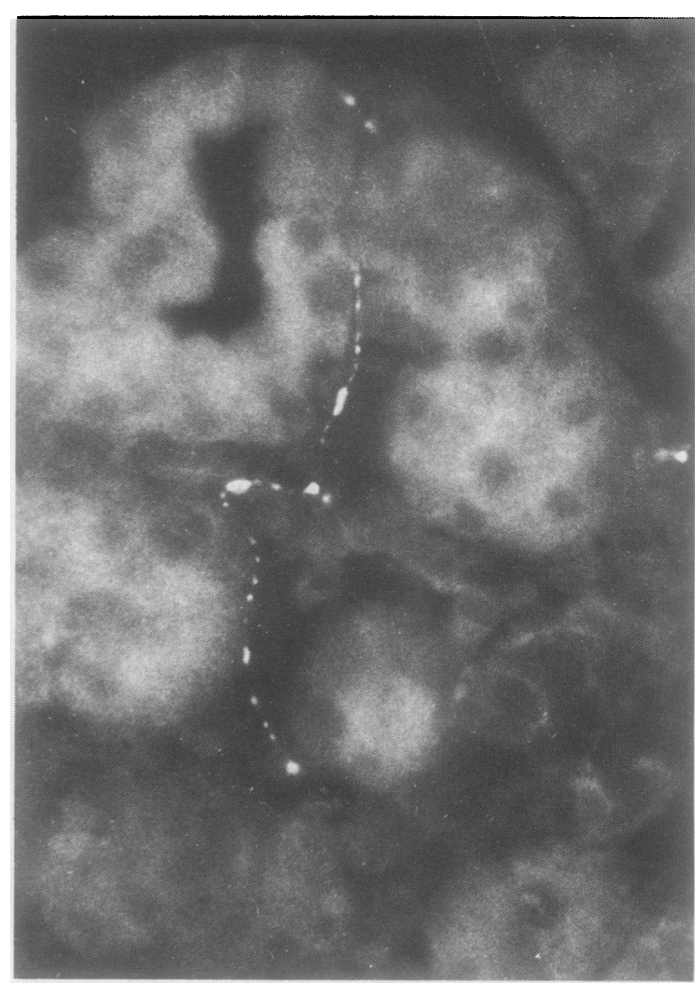

Fig 4 Galanin nerve fibres around the acini of seromucous glands in porcine trachea (indirect immunofluorescence, $\times 500$.

among seromucous glands, around blood vessels, in airway smooth muscles, and in ganglion cells. In the trachea and bronchus of the pig and dog, a close comparison of adjacent sections stained with vasoactive intestinal polypeptide and galanin antisera showed that several cell bodies displayed both galanin and vasoactive intestinal polypeptide immunoreactivities.

\section{RA DIOIMMUNOASSA Y}

The distribution of galanin immunoreactivity in the respiratory tract of the guinea pig, rat, and dog is shown in table 2 and 3 . The highest galanin concentrations in these species were found in the bronchi, with the lowest concentrations in the lung or outer lung. Friedman's two way analysis of variance by ranks showed that these differences were significant $(p$ $<0.01)$. The two specimens of pig respiratory tract (table 4) showed lower galanin concentrations than those from the other species, with the highest values in the trachea and the lowest in the lung.

CHROMATOGRA PHY

The porcine galanin standard emerged at a mean (SE) 


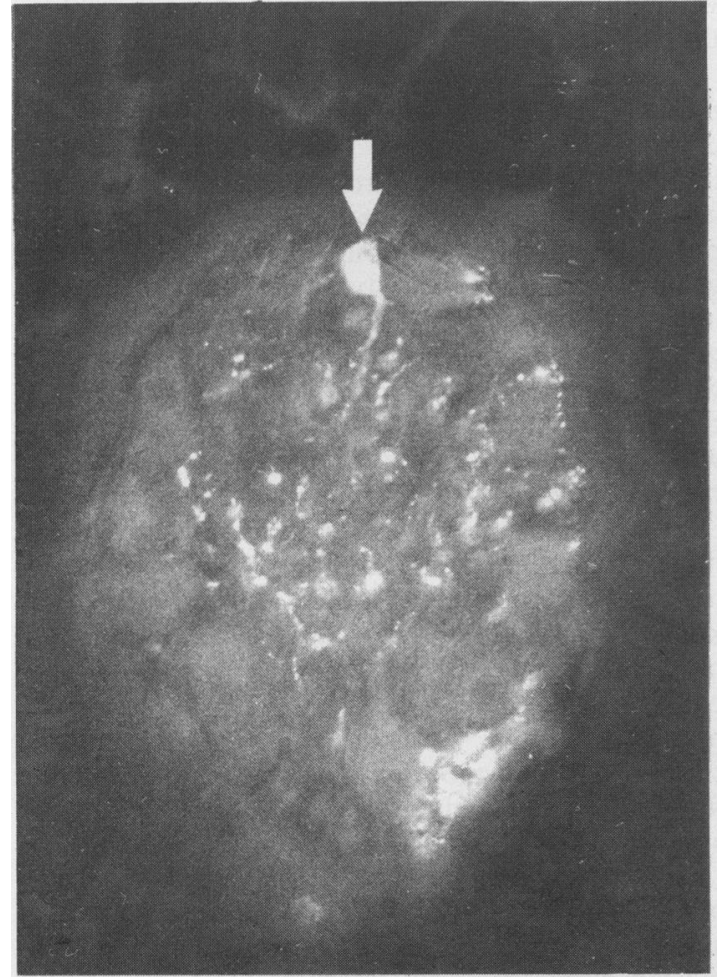

Fig 5 Galanin immunoreactive ganglion cell (arrow) in the adventitia of the porcine lower trachea (indirect immunofluorescence, $\times$ 270.)

Table 2 Regional distribution of galanin immunoreactivity in the respiratory tract of the guinea pig and rat (five animals in each case)

\begin{tabular}{lll}
\hline & \multicolumn{2}{l}{ pmol/g wet weight of tissue (mean(SD)) } \\
\cline { 2 - 3 } & Guinea pig & Rat \\
\hline Trachea & $1.8(0.8)$ & $1.6(0.1)$ \\
Bronchus & $2.2(0.6)$ & $1.9(0.4)$ \\
Lung & $1.3(0.3)$ & $0.9(0.3)$ \\
\hline
\end{tabular}

Table 3 Regional distribution of galanin immunoreactivity in the respiratory tract of the dog (five animals)

\begin{tabular}{ll}
\hline & $\begin{array}{l}\text { pmol/g wet weight of tissue } \\
(\text { mean }(S D))\end{array}$ \\
\hline Upper trachea & $1.5(0.4)$ \\
Lower trachea & $2.1(0.4)$ \\
Bronchus & $3.1(0.7)$ \\
Inner lung & $2.7(1.0)$ \\
Middle lung & $2.5(0.7)$ \\
Outer lung & $1.2(0.4)$ \\
\hline
\end{tabular}

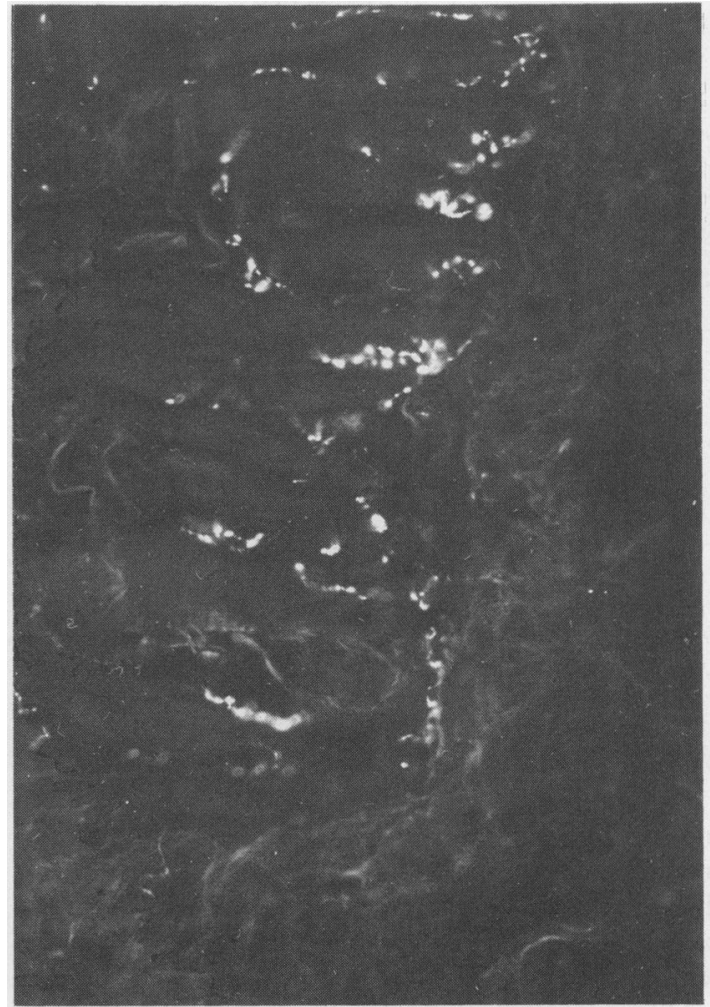

Fig 6 Galanin immunoreactive nerve fibres in the smooth muscles of intrapulmonary airway in the dog (indirect immunofluorescence, $\times 280$.)

Table 4 Regional distribution of galanin immunoreactivity in the respiratory tract of the pig (two animals)

\begin{tabular}{lll}
\hline & \multicolumn{2}{l}{$p m o l / g$ wet weight of tissue (mean) } \\
\cline { 2 - 3 } & Pig $l$ & Pig 2 \\
\hline Nasal mucosa & 0.43 & 0.34 \\
Upper trachea & 0.69 & 0.65 \\
Middle trachea & 0.58 & 0.38 \\
Lower trachea & 0.70 & 0.70 \\
Bronchus & 0.32 & 0.53 \\
Outer lung & 0.17 & 0.19 \\
Middle lung & 0.16 & 0.19 \\
Inner lung & 0.18 & 0.20 \\
\hline
\end{tabular}

Kav of $0.68(0.01)$. The galanin immunoreactivity of the pig trachea coeluted with the galanin standard in one single peak at Kav 0.68(0.01) (fig 7). The recoveries of all runs were $85-100 \%$.

\section{Discussion}

The newly isolated peptide galanin has been localised 
Pig trachea
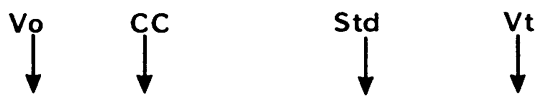

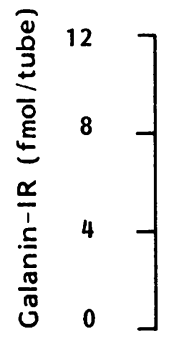

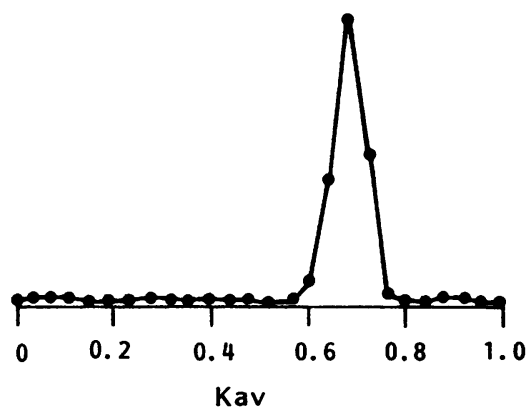

Fig 7 Representative gel permeation chromatographic profile of galanin immunoreactivity containing a pig trachea extract on a sephadex $G 50$ superfine column (100 $\times$ $1.5 \mathrm{~cm})$. Arrows indicate elution position of dextran blue (Vo), horse heart cytochrome $C(C C)$, porcine galanin standard (Std), and sodium iodine $125(\mathrm{Vt})$.

in the mammalian respiratory tract by immunocytochemical methods and radioimmunoassay. Its discovery in this organ adds to the increasing number of peptides found in the mammalian respiratory system.

Quantitative analysis of galanin demonstrated immunoreactivity in the respiratory tract of all species examined. Species differences in the galanin concentrations were, however, evident. Furthermore, galanin immunoreactivity in the airways was found to be higher than that in the lung. This is in accordance with the findings for vasoactive intestinal polypeptide, ${ }^{19} 20$ peptide histidine isoleucine, ${ }^{21}$ and substance $P,{ }^{1718}$ which also were found in higher concentrations in this part of the respiratory system.

Gel chromatographic analysis of pig trachea extracts showed one molecular form coeluting with the porcine standard, indicating roughly the same molecular size.

Immunocytochemical study has shown that galanin is present exclusively in nerve fibres with more in the upper part of the respiratory system, from the nasal mucosa down to the level of the major bronchi. These galanin immunoreactive fibres innervate structures like airway smooth muscle, seromucous glands, blood vessels, and the epithelium of the nasal mucosa. The existence of galanin immunoreactive cell bodies in the adventitia of the trachea and bronchi indicates that at least some of the galanin fibres may have an intrinsic origin. This hypothesis is reinforced by the fact that vasoactive intestinal polypeptide immunoreactivity was localised in ganglion cells also immunostained with antibody to galanin in the trachea and bronchi of the dog and pig.

In agreement with the quantitative analysis, the immunocytochemical study has revealed species differences in the galanin distributions. In the dog immunoreactive nerve fibres were mostly associated with smooth muscles, particularly in the intrapulmonary airways. Although the concentrations of galanin immunoreactivity detected by radioimmunoassay of tissue extracts were similar in the guinea pig and rat, no immunostained nerve fibres were found in the rat respiratory tract. This suggests that in the rat the peptide may be folded in a way which renders antigenic determinants unavailable to the antibodies used in the present study.

The distribution of galanin immunoreactive nerve fibres around blood vessels and in the smooth muscle in the respiratory tract is interesting in view of the known contractile effect of this peptide on smooth muscle preparations. ${ }^{1}$ Furthermore, there is evidence of abundant galanin containing fibres in the smooth muscle of the gut. ${ }^{31}$ Possibly galanin participates in the regulation of smooth muscle tone and local blood flow as well as glandular secretion in the respiratory system.

The parasympathetic and sympathetic innervation of the respiratory tract can be visualised by use of acetylcholinesterase and antibodies to dopamine- $\beta$ hydroxylase respectively. Recently, antibodies to neurone specific enolase and neurofilament protein have been used to delineate the entire innervation of the respiratory tract. ${ }^{3233}$ Despite species specificity, both acetylcholinesterase positive and DBH-containing nerves are generally well-represented in the upper part of the respiratory system ${ }^{32}$. Acetylcholinesterasepositive nerves supply blood vessels, seromucous glands, airway smooth muscle of the tracheobronchial tree $^{2432}$. Nerves containing dopamine- $\beta$-hydroxylase are found mainly around blood vessels and smooth muscle. No local cell bodies reacting to dopamine- $\beta$ hydroxylase antibodies have been located in the respiratory tract. ${ }^{32}$ Our observations seem to indicate that galanin immunoreactivity is found in locations similar to those of acetylcholinesterase positive nerves. Acetylcholesterase, however, has its limitations as a specific marker for cholinergic fibres since acetylcholinesterase staining also demonstrates peptidases, ${ }^{34}$ and this enzyme is known to hydrolyse substance $P{ }^{35}$ Antibodies to choline acetyltransferase are more specific markers for cholinergic neurones, ${ }^{3637}$ but information on the distribution of choline acetyltransferase immunoreactivity in the respiratory tract is lacking.

By comparison with other neuropeptides previously identified in the innervation of the respiratory tract, the distribution of galanin fibres around seromucous 
glands and blood vessels and among airway smooth muscle is similar to that of vasoactive intestinal polypeptide, ${ }^{1920}$ peptide histidine isoleucine,${ }^{21}$ and substance $P .{ }^{1819}$ These peptides all have a graded distribution, with more immunoreactive nerve fibres in the upper part of the tract than in the lung periphery. Nerve fibres immunoreactive for the sensory neuropeptide substance $P$ are particularly evident beneath the respiratory epithelium. ${ }^{1718}$ Galanin fibres have also been localised under the epithelium of the porcine nasal mucosa, but by comparison with substance $P$ they occur infrequently. As, however, the distribution of galanin in the dorsal horn of the spinal cord and in the dorsal root ganglia ${ }^{34}$ suggests a possible sensory role for this neuropeptide, the galanin fibres associated with the respiratory epithelium may have a sensory function. Like galanin, vasoactive intestinal polypeptide and peptide histidine isoleucine have had immunoreactivity demonstrated in local ganglia of the tracheobronchial wall. ${ }^{192124}$ In the mammalian enteric system, galanin is also found to be localised with vasoactive intestinal polypeptide in a subpopulation of ganglion cells of the submucous plexus. $^{31}$

Neuropeptide tyrosine, a novel peptide associated with sympathetic nerves, has been localised exclusively to nerve fibres in the mammalian respiratory system. Neuropeptide tyrosine immunoreactive nerves are also found in the adventitia of blood vessels and in airway smooth muscle. ${ }^{22}$ The distribution of this neuropeptide differs, however, from that of galanin in that nerve fibres immunoreactive for neuropeptide tyrosine are usually not found around seromucous glands. Furthermore, nerve fibres containing it do not appear to have an intrinsic origin since no neuropeptide tyrosine immunoreactive ganglion cells have been identified in the respiratory tract. ${ }^{22}$

It is beyond the scope of light microscopic studies to establish whether two peptides coexist in the same nerve fibres by comparing serial sections. Unlike the submucous plexus of the porcine duodenum, where half the total neurones in a group are immunoreactive for galanin, ${ }^{31}$ galanin immuoreactive ganglion cells are few and difficult to locate in the respiratory tract. Nevertheless, the fact that some ganglion cell bodies can be stained by antisera to both galanin and vasoactive intestinal polypeptide in the trachea and bronchi of the pig and dog strongly suggests that galanin coexists with another peptide in the mammalian respiratory tract.

Now that the occurrence and distribution of galanin immunoreactivity have been demonstrated in the respiratory tract further investigations, designed to clarify the nature and function of this novel peptide, are clearly warranted.

A Cheung is a visiting colleague from Hong Kong, supported by a Croucher Foundation fellowship, and A Cadieux a visiting colleague from Canada, supported by L'Institut de Recherche en Santé et en Securité du Travail du Québec. This work was supported in part by the Medical Research Council and the United States Council for Tobacco Research. The generous gift of pure natural galanin by $\mathrm{Dr} K$ Tatemoto is greatly appreciated.

\section{References}

1 Tatemoto K, Rökaeus A, Jörnvall H, McDonald TJ, Mutt V. Galanin - a novel biologically active peptide from porcine intestine. FEBS Let 1983;164:124-8.

2 McDonald TJ, Dupre J, Tatemoto K, Greenberg GR, Radzuik J, Mutt V. Galanin inhibits insulin secretion and induces hyperglycaemia in dogs. Diabetes 1985;34:192-6.

3 Rökaeus A, Melander T, Hökfelt T, et al. A galanin-like peptide in the central nervous system and intestine of the rat. Neurosci Lett 1984;47:161-6.

$4 \mathrm{Su}$ HC, Gibson SJ, Alford H, et al. The distribution and origin of galanin-immunoreactivity in the mammalian spinal cord. Consejo Superior de Investigaciones Cientificas, Trajajos del Instituto Cajal 1984;75, suppl: 124.

5 Bauer FE, Christofides ND, Gu J, et al. Distribution of galanin immunoreactivity in the urogenital tract of man and rat. Regul Pept 1984;9:325.

6 Nadel JA, Barnes PJ. Autonomic regulation of the airways. Annu Rev Med 1984;35:451-67.

7 Grundström N, Andersson RGG. A non-cholinergic non-adrenergic neuronal component mediating slow declining contraction in guinea-pig airways (abstract). $\mathrm{Br} J$ Pharmacol 1982;77:398P.

8 Andersson RGG, Grundström N. The excitatory noncholinergic, non-adrenergic nervous system of the guinea pig airways. Eur J Respir Dis 1983;64, suppl 131:141-57.

9 Peatfield AC, Richardson PS. Evidence for noncholinergic, non-adrenergic nervous control of mucus secretion into the cat trachea. $J$ Physiol (Lond) 1983;342:335-45.

10 Barnes PJ. Third nervous system in the lung: physiology and clinical perspectives. Thorax 1984;39:61-7.

11 Polak JM, Bloom SR. Distribution of regulatory peptides in the respiratory tract of man and mammals. In: Bloom SR, Polak JM, Lindenlaub E, eds. Systemic role of regulatory peptides, Stuttgart: FK Schattauer Verlag, 1982:241-69.

12 Wharton J, Polak JM, Bloom SR, et al. Bombesin-like immunoreactivity in the lung. Nature 1978;273:769-70.

13 Becker KL, Monaghan KG, Silva OL. Immunocytochemical localisations of calcitonin in Kultschitzky cells of human lung. Arch Pathol Lab Med 1980;104:196-8.

14 Cutz E, Chan W, Trach NS. Bombesin, calcitonin and leu-enkephalin immunoreactivity in endocrine cell of human lung. Experientia 1981;37:765-7.

15 Sissons MCJ, Gosney JR, Heath D. Calcitonincontaining cells in lungs of foetal and neonatal rats (abstract). J Pathol 1984;143:307A.

16 Gosney JR, Sissons MCJ, Heath D. Bronchopulmonary endocrine cells immunoreactive for calcitonin in normal adult rat lung (abstract). J Pathol 1984;143:307A.

17 Nilsson G, Dahlberg K, Brodin E, Sundler F, Strandberg K. Distribution and constrictor effect of substance $P$ in 
guinea pig tracheobronchial tissue. In: von Euler US, Pernow B, eds. Substance P. New York: Raven Press, 1977:75-81.

18 Wharton J, Polak JM, Bloom SR, Will JA, Pearse AGE. Substance P-like immunoreactive nerves in mammalian lung. Invest Cell Pathol 1979;2:3-10.

19 Uddman R, Alumets J, Densert O, Hakanson R, Sundler F. Occurrence and distribution of VIP nerves in the nasal mucosa and tracheo-bronchial wall. Acta Otolaryngol (Stockh) 1978;86:443-8.

20 Dey RD, Shannon WA Jr, Said SI. Localisation of VIPimmunoreactive nerves in airways and pulmonary vessels of dogs, cats and human subjects. Cell Tissue Res 1981;220:231-8.

21 Christofides ND, Yiangou Y, Piper PJ, et al. Distribution of peptide histidine isoleucine (PHI) in the mammalian respiratory tract and some aspects of its pharmacology. Endocrinology 1984;115:1958-63.

22 Sheppard MN, Polak JM, Bloom SR. Neuropeptide tyrosine (NPY): a newly discovered peptide is present in mammalian respiratory tract. Thorax 1984;39:326-330.

23 Springall DR, Polak JM, Ghatei MA, Lackie P, Bloom SR. Calcitonin gene-related peptide (CGRP) - a new regulatory peptide widely distributed in lung (abstract). $J$ Pathol 1984;143:306A.

24 Ghatei MA, Sheppard MN, O'Shaughnessy DJ, et al. Regulatory peptides in the mammalian respiratory tract. Endocrinology 1982;111:1248-54.

25 Bishop AE, Polak JM, Bloom SR, Pearse AGE. A new universal technique for the immunocytochemical localisation of peptidergic innervation. $J$ Endocrinol 1978;71:25-6.

26 Huang WM, Gibson SJ, Facer P, Gu J, Polak JM. Improved section adhesion for immuncytochemistry using high molecular weight polymers of L-lysine as a slide coating. Histochemistry 1983;77:275-9.

27 Coons AH, Leduc EH, Connolly JM. Studies on anti- body production-I. A method of the histochemical demonstration of specific antibody and its application to a study of the hyperimmune rabbit. $J$ Exp Med 1955;102:49-60.

28 Ch'ng JLC, Christofides ND, Anand P, et al. Distribution of galanin immunoreactivity in central nervous system and the response of galanin-containing neurol pathways to injury. Neurosci Lett (in press).

29 Laurent TC, Killander J. A theory of gel filtration and its experimental verification. J Chromatogr 1964;14:317-30.

30 Siegel S. Nonparametric statistics for the behavioural sciences. McGraw-Hill: New York, 1956:166-73.

31 Bishop AE, Christofides ND, Bauer E, Tatemoto K, Bloom SR, Polak JM. Galanin: a newly recognised peptide in the enteric nervous system (abstract). Reg Pep 1984;9:325.

32 Sheppard MN, Kurian SS, Henzen-Logmans SC, et al. Neuron specific enolase and S-100: new markers for delineating the innervation of the respiratory tract in man and other mammals. Thorax 1983;38:333-40.

33 Hacker GW, Polak JM, Springall DR, et al. Antibodies to neurofilament protein and other brain proteins reveal the innervation of peripheral organs. Histochemistry 1985;82:581-593.

34 Pepler WJ, Pearse AGE. The histochemistry of the esterases of rat brain with specific reference to those of the hypothalamic nuclei. $J$ Neurochem 1957;1:193-202.

35 Chubb IW, Hodgson AJ, White GH. Acetylcholinesterase hydrolyses substance P. Neuroscience 1980;5:2065-72.

36 Eckenstein F, Barde YA, Thoenen H. Production of specific antibodies to choline acetyltransferase purified from pig brain. Neuroscience 1981;6:993-1000.

37 Eckenstein F, Thoenen H. Production of specific antisera and monoclonal antibodies to choline acetyltransferase: characterisation and use for identification of cholinergic neurons. EMBO Journal 1982;1:363-8. 